\title{
Oxidative stress markers are increased in non-alcoholic fatty liver disease patients with high serum alanine aminotransferase levels
}

\section{Podwyższenie wartości markerów stresu oksydacyjnego u pacjentów z niealkoholową stłuszczeniową chorobą wątroby z wysokim stężeniem aminotransferazy alaninowej w surowicy}

\author{
Suzan Muratoglu Severcan ${ }^{1}$, Ayse Bilgihan², Gulbanu Erkan², Ugur Ercin², Cinar Severcan ${ }^{4}$ \\ ${ }^{1}$ Department of Medical Biochemistry, Institute of Health Sciences, Gazi University, Ankara, Turkey \\ Head of the Department: Prof. Dr. Neslihan Bukan \\ ${ }^{2}$ Department of Medical Biochemistry, Medical Faculty, Ufuk University, Ankara, Turkey \\ Head of the Department: Prof. Dr. Ayse Bilgihan \\ ${ }^{3}$ Division of Gastroenterology, Department of Internal Medicine, Istanbul Medipol University, Istanbul, Turkey \\ Head of the Division: Prof. Dr. Esin Korkut \\ ${ }^{4}$ Department of Biochemistry, Faculty of Pharmacy, Zonguldak Bulent Ecevit University, Zonguldak, Turkey \\ Head of the Department: Assist. Prof. Ayse Ceylan Hamamcioglu
}

Medical Studies/Studia Medyczne 2019; 35 (4): 283-287 DOI: https://doi.org/10.5114/ms.2019.91245

Key words: inflammation, oxidative stress, alanine aminotransferase, non-alcoholic fatty liver disease.

Słowa kluczowe: stan zapalny, stres oksydacyjny, aminotransferaza alaninowa, niealkoholowa stłuszczeniowa choroba wątroby.

\begin{abstract}
Introduction: Non-alcoholic fatty liver disease (NAFLD) is a pathological disease that causes chronic damage in the liver without alcohol consumption.

Aim of the research: To determine oxidative stress and inflammation statuses (NAFLD) with increased alanine aminotransferase (ALT).

Material and methods: Oxidative stress (malondialdehyde (MDA), advanced oxidation protein products (AOPP), inflammation (serum tumour necrosis factor- $\alpha$ (TNF- $\alpha$ )), interleukin-6 (IL-6), and hyaluronic acid (HA) were measured by the ELISA method or manually. A total of 133 non-obese and non-diabetic individuals were included. Patients diagnosed with NAFLD with normal ALT levels were included in group $1(n=53)$, and those with high ALT levels were included in group $2(n=35)$. The control group included individuals without any known systemic disease $(n=45)$.

Results: We found that the serum MDA levels were significantly elevated in group 2 in comparison to the control group $(p<0.05)$. However, there were no significant changes in the serum AOPP levels in any group $(\mathrm{p}>0.05)$. The serum TNF- $\alpha$ and IL-6 levels of group 1 and group 2 were higher than those in the control group $(p<0.05)$. The serum HA levels in group 2 increased significantly in comparison to the other groups $(p<0.05)$.

Conclusions: HA and MDA were enhanced with high ALT levels and with elevated TNF- $\alpha$ and IL-6 levels without high ALT levels in NAFLD.
\end{abstract}

\section{Streszczenie}

Wprowadzenie: Niealkoholowa stłuszczeniowa choroba wątroby (NAFLD) jest schorzeniem wywołującym przewlekłe uszkodzenie wątroby, którego przyczyną są inne czynniki niż nadmierne spożycie alkoholu.

Cel pracy: Oznaczenie stresu oksydacyjnego i występowania stanu zapalnego u pacjentów z NAFLD z podwyższoną aktywnością aminotransferazy alaninowej (ALT).

Materiał i metody: Markery stresu oksydacyjnego (aldehyd dimalonowy (MDA) i zaawansowane produkty utleniania białek (AOPP)) oraz stanu zapalnego (czynnik martwicy nowotworów $\alpha$ (TNF- $\alpha$ )), interleukina-6 (IL-6) i kwas hialuronowy (HA)) w surowicy oznaczano testem ELISA lub metodą manualną. Do badania włączono ogółem 133 osoby bez nadwagi i cukrzycy. Pacjentów z rozpoznaniem NAFLD, u których stężenie ALT było prawidłowe, włączono do grupy 1. $(n=53)$, natomiast chorych z NAFLD i wysokim stężeniem ALT - do grupy 2. $(n=35)$. Grupa kontrolna obejmowała osoby, u których nie występowały żadne znane choroby ogólnoustrojowe $(n=45)$.

Wyniki: Stwierdzono, że stężenia MDA w surowicy w grupie 2. są istotnie podwyższone w porównaniu z grupą kontrolną $(p<0,05)$. Nie odnotowano natomiast istotnych zmian w stężeniach AOPP $\mathrm{w}$ surowicy w żadnej z grup $(p>0,05)$. Stężenia 
TNF- $\alpha$ i IL-6 w surowicy w grupie 1. i 2. były wyższe niż w grupie kontrolnej ( $p<0,05)$. Stężenie HA w surowicy w grupie 2. było istotnie podwyższone w stosunku do pozostałych grup $(p<0,05)$.

Wnioski: W badaniu wykazano podwyższone stężenia HA i MDA u pacjentów z NAFLD z wysokim stężeniem ALT oraz podwyższone stężenia TNF- $\alpha$ i IL-6 u osób z NAFLD z prawidłowym stężeniem ALT.

\section{Introduction}

Non-alcoholic fatty liver disease (NAFLD) causes chronic damage in the liver [1]. NAFLD is a pathological condition that is seen in persons who do not drink alcohol but are still susceptible to fat accumulating around the liver. The pathogenesis of NAFLD is multifactorial, which explains the "two-hit" traditional hypothesis. The first hit consists of aggregation of fatty acids/triglycerides (TGs) in the liver and impairment of insulin resistance (IR) response. The second hit is increased oxidative stress and inflammatory response. Eventually, two hits result in liver injury $[2,3]$. An increased serum alanine aminotransferase (ALT) level is an indicator of NAFLD if auto-immune diseases, viruses, and medicines are excluded. However, in some patients, despite the normal ALT levels, these diseases may be seen in histopathology [4].

Lipid peroxidation begins by removing hydrogen atoms contained in the $\alpha$-methylene group of polyunsaturated fatty acid chains from the membrane structure, as a result of the free radical effect. Lipid peroxidation is terminated with lipid hydroperoxide that is converted to aldehydes and other carbonyl compounds. The level of one of these compounds, malondialdehyde (MDA), is measured by the thiobarbituric acid test, and this method is often used to detect lipid peroxide levels [5]. A membrane protein that has an enzymatic function and the receptor are sensitive to free radical modification. This causes protein oxidation with cell and membrane defects. Determination of protein carbonyl is widely used to recognise the damage to the protein structure. Advanced oxidation protein products (AOPP) are a marker of protein oxidation and defined as cross-linked protein products that contain dityrosine. They are known as valuable markers of oxidative protein modifications [6]. The oxidative stress increases with advanced levels of NAFLD, and it is observed that it has a role in the disease's steatosis and advancement into steatohepatitis [7]. Hyaluronic acid (HA) is a natural polysaccharide, which is made out of the disaccharide units of glucuronic acid and $\mathrm{N}$-acetylglucosamine. It is stated that HA may be beneficial in distinguishing people who have non-alcoholic fatty liver disease and those who have non-alcoholic steatohepatitis, and it is acknowledged that HA is an important parameter for showing liver fibrosis in chronic hepatitis [8].

TNF- $\alpha(26 \mathrm{kDa})$ is a transmembrane protein (TNF- $\alpha$ ) in adipocytes. TNF- $\alpha$ regulates many inflammatory and autoimmune processes. For persons suffering from obesity, the elevated level of TNF- $\alpha$ depends on hyperinsulinaemia, which induces insulin resistance in peripheral tissues [9]. Interleukin-6 (IL-6) is a cytokine synthesised by mononuclear phagocytes, vascular endothelial cells, fibroblasts, epithelial cells, and activated T cells [10]. IL-6 is significantly correlated with increasing visceral fat and insulin resistance, and it independently predicts increasing hepatic inflammation. Interleukin- 6 and TNF- $\alpha$ are pro-inflammatory cytokines. It is considered that TNF- $\alpha$ constitutes the second hit, which is determinant in the transformation of fatty liver to progressive disease forms [11].

\section{Aim of the research}

This study classified NAFLD patients based on their increased ALT levels. The aim of this study was to determine the oxidative stress and inflammation statuses in NAFLD by examining MDA, AOPP, TNF- $\alpha$, IL-6, and HA levels. These parameters play some roles in the pathogenesis and progression of this disease.

\section{Material and methods}

This study included a total of 133 non-obese and non-diabetic individuals who visited clinics with a dyspeptic symptom or for routine check-up procedures. The groups were categorised based on their serum ALT levels and ultrasonography findings. The groups were formed as follows: patients diagnosed with non-alcoholic fatty liver disease with normal ALT levels as were defined as group $1(n=53)$; patients diagnosed with non-alcoholic fatty liver disease with high ALT levels as group $2(n=35)$; and the control group included individuals without any known systemic disease $(n=45)$. The inclusion criteria were as follows: presence of hepatosteatosis in USG for groups 1 and 2; the presence of negative markers such as viral, autoimmune, and metabolic liver diseases; and no ethanol intake. The exclusion criteria included diabetes mellitus, drugs that can lead to type 2 diabetes (steroids), and drugs that can cause hepatosteatosis (e.g. steroids, oral contraceptives, methotrexate, tetracycline, amiodarone). The serum level of ALT was measured by using an autoanalyser in routine biochemistry laboratory.

Lipid peroxidation determines the reaction that occurs between MDA and thiobarbituric acid under acidic conditions, and the pink-coloured product is measured spectrophotometrically at $532 \mathrm{~nm}$. MDAconcentration was recorded in units of " $\mathrm{nmol} \mathrm{MDA} / \mathrm{ml}$ ". The AOPP level was determined by spectrophotometric methods. Procedures were performed for chlorinated oxidants and crosslinking products of serum 
protein, which are oxidised by potassium iodide. Next, the absorbance of the released chemical potassium iodide was immediately measured against the PBS solution at $340 \mathrm{~nm}$. Chloramine-T solutions had levels of concentration from $6.25 \mu \mathrm{mol} / 1$ to $100 \mu \mathrm{mol} / 1$. These figures were used in drawing a standard curve. AOPP concentrations were found in chloramine-T equivalents, measured in $\mu \mathrm{mol} / \mathrm{l}$ units. The coefficient of variation HA (Cusabio, catalogue no: CSB-E04805h), TNF- $\alpha$ (Diasource, catalogue no: KAP 1751), and IL-6 (Diasource, catalogue no: KAP1261) serum levels of all patients were studied by using the ELISA method.

\section{Statistical analysis}

SPSS (Statistical Package for the Social Sciences) version 18.0 was used to analyse the data, which were obtained and tabulated. Shapiro-Wilk test was used to test the parametric test conditions. The data showed non-parametric test conditions according to the Shapiro-Wilk test. Consequently, the Mann-Whitney $U$ test, which is a non-parametric test, was chosen to compare two independent groups. In all statistical analyses, the significance level was accepted as $p \leq 0.05$. Correlation analyses were performed using Spearman's correlation test.

\section{Results}

Table 1 shows the mean and standard deviation values of the demographic variables, and Table 2 shows the mean and standard deviation values for the biochemical variables of all groups.

The mean ages of the control, group 1 , and group 2 were $34.75,56.28$, and 45.06 , the mean body mass index (BMI) values of these groups were 22.57, 23.36, and $24.25 \mathrm{~kg} / \mathrm{m}^{2}$, and the mean ALT levels of these groups were 17.71, 22.96, and 72.91, respectively (Table 1).

The serum MDA levels increased significantly in group 2 (high level of ALT) in comparison to the control group $(p=0.012)$, while there was no significant difference between group 1 (low level of ALT) and group $2(p>0.05)$. There were no significant changes in the AOPP levels amongst the groups $(p>0.05)$. The serum TNF- $\alpha$ levels in groups 1 and 2 were significantly higher than those in the control group ( $p=0.01$ and $p=0.011$, respectively). However, there
Table 1. List of mean levels of demographic characters of the all groups

\begin{tabular}{|lccc|}
\hline Parameter & $\begin{array}{c}\text { Control group } \\
(n=45)\end{array}$ & $\begin{array}{c}\text { Group 1 } \\
(n=53)\end{array}$ & $\begin{array}{c}\text { Group 2 } \\
(n=35)\end{array}$ \\
Age & 34.75 & 56.28 & 45.06 \\
BMI & 22.57 & 23.36 & 24.25 \\
ALT [IU/I] & 17.71 & 22.96 & 72.91 \\
\hline
\end{tabular}

$N$-number of patients, $B M I$ - body mass index, $A L T$ - alanine aminotransferase.

was no significant difference between groups 1 and 2 $(p>0.05)$. A significant change in the serum IL-6 levels was also found amongst all groups $(p=0.001)$. The serum IL-6 levels increased significantly in groups 1 and 2 in comparison to the control group ( $p=0.01$ and $p=0.001$, respectively), and the values in group 2 were significantly higher than those in group 1 ( $p=0.001)$. A significant rise of HA levels was measured in group 2 in comparison to the control group and group 1 ( $p=0.002$ and $p=0.038$, respectively) (Table 2).

On other hand, according to the Spearman's correlation test results, the MDA and AOPP levels increased simultaneously. There was a strong correlation between the MDA and AOPP levels $\left(r^{2}=0.422\right.$, $p<0.01)$. There was also a strong correlation between the TNF- $\alpha$ and IL- 6 levels $\left(r^{2}=0.422, p<0.01\right)$ (Table 3).

\section{Discussion}

Major metabolites (glucose, fatty acids, and cholesterol) play a key role in the well-being of the liver. Obesity as a result of poor dietary habits leads to increased insulin resistance of the peripheral tissues, which causes an accumulation of fat in the liver [1214]. As a result of this, NAFLD may spread [14-17]. NAFLD is a disorder that is frequently found within blood abnormalities. Younossi et al. [18] determined high aminotransferase enzyme levels in the US general population, measured at $1 \%$ to $9 \%$, and the majority of patients who were diagnosed with hypertransaminasaemia had levels at 3\% to 5\% and reported symptoms of NAFLD. NAFLD is generally associated with insulin resistance, which leads to type 2 diabetes and obesity. Ghamar-Chehreh et al. [19] reported that, in NAFLD, increased levels of ALT were not correlated

Table 2. List of mean \pm standard deviation levels and the coefficient of variations biochemical values of all groups.

\begin{tabular}{|lccc|}
\hline Parameter & Control group $(n=45)$ & Group $1(n=53)$ & Group 2 $(n=35)$ \\
MDA $[\mathrm{nmol} / \mathrm{ml}]$ & $1.65 \pm 0.69$ & $1.89 \pm 0.97$ & $2.04 \pm 0.67^{\mathrm{b}}$ \\
AOPP $[\mu \mathrm{mol} / \mathrm{l}]$ & $37.35 \pm 16.71$ & $40.73 \pm 16.65$ & $42.14 \pm 17.07$ \\
IL-6 $[\mathrm{pg} / \mathrm{ml}]$ & $17.92 \pm 5.27$ & $21.09 \pm 6.94^{\mathrm{a}}$ & $32.24 \pm 38.84^{\mathrm{b}, \mathrm{c}}$ \\
TNF- $\alpha[\mathrm{pg} / \mathrm{ml}]$ & $4.55 \pm 3.05$ & $5.86 \pm 2.71^{\mathrm{a}}$ & $6.20 \pm 3.24^{\mathrm{b}}$ \\
HA $[\mathrm{ng} / \mathrm{ml}]$ & $0.48 \pm 0.37$ & $0.5 \pm 0.32$ & $0.6 \pm 0.35^{\mathrm{b}, \mathrm{c}}$ \\
\hline
\end{tabular}

$n$ - number of patients, ${ }^{a}$ significance $p \leq 0.05$; difference between control group and group 1, ${ }^{b}$ significance $p \leq 0.05$; difference between control group and group 2, csignificance $p \leq 0.05$; difference between group 1 and group 2. 
Table 3. Correlation analyses among the parameters

\begin{tabular}{|cccccc|}
\hline \multirow{4}{*}{ MDA } & & MDA & AOPP & TNF- $\alpha$ & IL-6 \\
& $r$ & 1 & 0.42 & - & - \\
\cline { 2 - 6 } & $p$ & - & $0.001^{*}$ & - & - \\
\cline { 2 - 6 } AOPP & $n$ & 130 & 130 & - & - \\
& $r$ & 0.42 & 1 & - & - \\
\cline { 2 - 6 } & $p$ & $0.001^{*}$ & - & - & - \\
\cline { 2 - 6 } TNF- $\alpha$ & $n$ & 130 & 130 & - & - \\
& $r$ & - & - & 1 & 0.254 \\
\cline { 2 - 6 } & $p$ & - & - & - & $0.004^{*}$ \\
\cline { 2 - 6 } IL-6 & $n$ & - & - & 130 & 130 \\
& $r$ & - & - & 0.254 & 1 \\
\cline { 2 - 6 } & $p$ & - & - & $0.004^{*}$ & - \\
\cline { 2 - 6 } & $n$ & - & - & 130 & 130 \\
\hline
\end{tabular}

*Significance correlation at the 0.01 level.

with dyslipidaemia but showed a correlation with insulin resistance. In livers with progressed damage, reduced hyaluronate receptors of sinusoidal endothelial cells induce high HA levels. Serum HA levels are a predictor of the progression of hepatic fibrosis. Accordingly, determining serum HA is a good marker to help diagnose hepatic fibrosis [20]. Suziki et al. [21] and Pawitpok et al. [22] reported that serum HA and ALT levels increase together, and that the disease changes from steatosis to fibrosis.

According to our results, the serum HA levels in this study significantly increased $(p<0.05)$ in group 2 in comparison to the control group and group 1. It was concluded that elevated ALT levels may induce HA without diagnosis of fibrosis in NAFLD. Loguercio et al. [23] stated that inflammation parameters such as TNF- $\alpha$ and IL- 6 increased significantly, along with the insulin resistance in NAFLD patients who had abnormally high serum ALT levels. In parallel to this, Jang et al. also showed increased ALT levels with inflammation markers [24]. Nevertheless, Wong et al. [25] did not mention any change reagrding an increase in ALT levels with TNF- $\alpha$ and IL-6. In this study, the TNF- $\alpha$ and IL- 6 levels increased significantly in groups 1 and 2 in comparison to the control group ( $p<0.05$ ). The IL-6 levels of group 2 were also measured, and it was noticed that they significantly increased in comparison to group $1(p<0.05)$. These results suggested that NAFLD may trigger a high level of inflammation, whereas increases in the ALT levels did not stimulate inflammatory parameters. In other words, these findings showed that TNF- $\alpha$ and IL-6 levels increased together $(p<0.01)$.

The levels of lipid peroxidation products are important in determining steatosis. Araya et al. [26] reported that the serum MDA levels increased significantly in comparison to the control group of steatosis and non-alcoholic steatohepatitis (NASH) patients, but there was no significant correlation in the serum ALT levels between these groups. Kumar et al. [27] reported that the serum levels of MDA were significantly higher among NAFLD patients with raised ALT levels in comparison to the control groups. Mousavi et al. [28] found similar results in a rat model. There was a contradiction between these studies in terms of the ALT levels. According the results in this study, while there were significantly increased serum MDA levels in group 2 in comparison to the control group, we did not find any significant difference with group 1 . This result showed that elevated ALT levels in NAFLD may increase lipid peroxidation. Protein damage occurs as a result of oxidative stress, as well as lipid peroxidation, in a fatty liver. There are a few studies in the literature on the AOPP levels in fatty liver disease. Nevertheless, different protein carboxylation and oxidation products were reported to increase [26, 29]. Araya et al. [26] observed that protein carboxylation increased significantly in the control group of NAFLD and NASH patients, but they could not measure any significant correlation between these groups. Videla et al. [29] showed that protein oxidation increased significantly in NAFLD patients in comparison to NASH and the control group. In our study, it was not possible to observe the significance of the differences of the AOPP levels of groups 1 and 2 in comparison to the control group $(p>0.05)$. However, there were strong positive correlations between MDA and AOPP $(p<0.01)$. Both MDA and AOPP levels increased together in NAFLD.

\section{Conclusions}

This study showed that HA and MDA were enhanced with high ALT levels and on elevated TNF- $\alpha$ and IL-6 levels without high ALT levels in NAFLD.

HA and MDA levels may be used as valuable markers for the diagnosis of NAFLD. Further studies are needed to clarify high ALT levels and biochemical parameters in the pathogenesis of NAFLD.

\section{Acknowledgments}

This project was approved by Gazi University Board of Local Ethics under the code G.Ü. ET. 070220122 and was supported financially by Gazi University Scientific Research Projects Unit under the project code 01/2012-14.

\section{Conflict of interest}

The authors declare no conflict of interest.

\section{References}

1. Fiorucci S, Biagioli M, Distrutti E. Future trends in the treatment of non-alcoholic steatohepatitis. Pharmacol Res 2018; 134: 289-298. 
2. Del Ben M, Polimeni L, Baratta F, Pastori D, Angelico F. The role of nutraceuticals for the treatment of non-alcoholic fatty liver disease. Br J Clin Pharmacol 2017; 83: 88-95.

3. Engin A. Non-alcoholic fatty liver disease. Adv Exp Med Biol 2017; 960: 443-467.

4. Tolman KG, Fonseca V, Ton MH, Dalplaz A. Narrative review: hepatobiliary disease in type 2 diabetes mellitus. Ann Intern Med 2004; 141: 946-956.

5. Bellanti F, Villani R, Facciorusso A, Vendemiale G, Serviddio G. Lipid oxidation products in the pathogenesis of non-alcoholic steatohepatitis. Free Radic Biol Med 2017; 111: 173-185.

6. Cristani M, Speciale A, Saija A, Gangemi S, Minciullo PL, Cimino F. Circulating advanced oxidation protein products as oxidative stress biomarkers and progression mediators in pathological conditions related to inflammation and immune dysregulation. Curr Med Chem 2016; 23: 3862-3882.

7. Spahis S, Delvin E, Borys JM, Levy E. Oxidative stress as a critical factor in nonalcoholic fatty liver disease pathogenesis. Antioxid Redox Signal 2017; 26: 519-541.

8. Gudowska M, Cylwik B, Chrostek L. The role of serum hyaluronic acid determination in the diagnosis of liver fibrosis. Acta Biochim Pol 2017; 64: 451-457.

9. Dludla PV, Nkambule BB, Jack B, Mkandla Z, Mutize T, Silvestri S, Orlando P, Tiano L, Louw J, Mazibuko-Mbeje SE. Inflammation and oxidative stress in an obese state and the protective effects of gallic acid. Nutrients 2018; 11: pii: E23.

10. Mauer J, Chaurasia B, Goldau J, Vogt MC, Ruud J, Nguyen KD, Theurich S, Hausen AC, Schmitz J, Brönneke HS Estevez E, Allen TL, Mesaros A, Partridge L, Febbraio MA, Chawla A, Wunderlich FT, Brüning JC. Signaling by IL-6 promotes alternative activation of macrophages to limit endotoxemia and obesity-associated resistance to insulin. Nat Immunol 2014; 15: 423-430.

11. Farrell GC, Larter CZ. Nonalcoholic fatty liver disease: from steatosis to cirrhosis. Hepatology 2006; 43 (2 Suppl 1): 99-112.

12. Suliga E, Kozieł D, Cieśla E, Rębak D, Głuszek S. Dietary patterns in relation to metabolic syndrome among adults in poland: a cross-sectional study. Nutrients 2017; 9: pii: E1366.

13. Suliga E, Kozieł D, Cieśla E, Rębak D, Głuszek S. Coffee consumption and the occurrence and intensity of metabolic syndrome: a cross-sectional study. Int J Food Sci Nutr 2017; 68: 507-513.

14. Ashtari S, Pourhoseingholi MA, Zali MR. Non-alcohol fatty liver disease in Asia: prevention and planning. World J Hepatol 2015; 7: 1788-1796.

15. Kontogianni MD, Tileli N, Margariti A, Georgoulis M, Deutsch M, Tiniakos D, Fragopoulou E, Zafiropoulou R, Manios Y, Papatheodoridis G. Adherence to the Mediterranean diet is associated with the severity of non-alcoholic fatty liver disease. Clin Nutr 2014; 33: 678-683.

16. Shahroukh HD, Davoodi M, Rahmani O, Roushanaei A, Seydeyan SM, Adel SMH. Association of nonalcoholic fatty liver with carotid intima-media thickness in patients with dyslipidaemia. Med Stud 2018; 34: 226-231.

17. Koo SH. Nonalcoholic fatty liver disease: molecular mechanisms for the hepatic steatosis. Clin Mol Hepatol 2013; 19: 210-215.

18. Younossi ZM, Koenig AB, Abdelatif D, Fazel Y, Henry L, Wymer M. Global epidemiology of nonalcoholic fatty li- ver disease-meta-analytic assessment of prevalence, incidence, and outcomes. Hepatology 2016; 64: 73-84.

19. Ghamar-Chehreh ME, Amini M, Khedmat H, Moayed Alavian S, Daraei F, Mohtashami R, Hadi R, Beyram BA, Taheri $\mathrm{S}$. Elevated alanine aminotransferase activity is not associated with dyslipidemias, but related to insulin resistance and higher disease grades in non-diabetic non-alcoholic fatty liver disease. Asian Pac J Trop Biomed 2012; 2: 702-706.

20. Orasan OH, Ciulei G, Cozma A, Sava M, Dumitrascu DL. Hyaluronic acid as a biomarker of fibrosis in chronic liver diseases of different etiologies. Clujul Med 2016; 89: 24-31.

21. Suzuki A, Angulo P, Lymp J, Li D, Satomura S, Lindor K. Hyaluronic acid, an accurate serum marker for severe hepatic fibrosis in patients with non-alcoholic fatty liver disease. Liver Int 2005; 25: 779-786.

22. Pawitpok C, Kongtawelert P, Ua-arayaporn S, Punyarit P, Piyanirun W, Chutaputti A. Efficacy of serum hyaluronic acid level for predicting liver fibrosis in patients with nonalcoholic fatty liver disease. Thai J Gastroenterol 2006; 7: 83-87.

23. Loguercio C, De Simone T, D’Auria MV, de Sio I, Federico A, Tuccillo C, Abbatecola AM, Del Vecchio Blanco C. Non-alcoholic fatty liver disease: a multicentre clinical study by the Italian Association for the Study of the Liver. Dig Liver Dis 2004; 36: 398-405.

24. Jiang W, Wu N, Wang X, Chi Y, Zhang Y, Qiu X, Hu Y, Li J, Liu Y. Dysbiosis gut microbiota associated with inflammation and impaired mucosal immune function in intestine of humans with non-alcoholic fatty liver disease. Sci Rep 2015; 5: 8096.

25. Wong VW, Wong GL, Choi PC, Chan AW, Li MK, Chan HY. Disease progression of non-alcoholic fatty liver disease: a prospective study with paired liver biopsies at 3 years. Gut 2010; 59: 969-974.

26. Araya J, Rodrigo R, Videla LA, Thielemann L, Orellana M, Pettinelli P, Poniachik J. Increase in long-chain polyunsaturated fatty acid n-6/n-3 ratio in relation to hepatic steatosis in patients with non-alcoholic fatty liver disease. Clin Sci 2004; 106: 635-643.

27. Kumar R, Prakash S, Chhabra S, Singla V, Madan K, Gupta SD. Association of pro-inflammatory cytokines, adipokines and oxidative stress with insulin resistance and non-alcoholic fatty liver disease. Indian J Med Res 2012; 136: 229-236.

28. Mousavi SN, Faghihi A, Motaghinejad M, Shiasi M, Imanparast F, Amiri HL, Shidfar F. Zinc and selenium co-supplementation reduces some lipid peroxidation and angiogenesis markers in a rat model of NAFLD-Fed high fat diet. Biol Trace Elem Res 2018; 181: 288-295.

29. Videla LA, Rodrigo R, Orellana M, Fernandez V, Tapia G, Quiñones L, Varela N, Contreras J, Lazarte R, Csendes A, Rojas J, Maluenda F, Burdiles P, Diaz JC, Smok G, Thielemann L, Poniachik J. Oxidative stress-related parameters in the liver of non-alcoholic fatty liver disease patients. Clin Sci 2004; 106: 261-268.

\section{Address for correspondence:}

\section{Suzan Muratoglu Severcan}

Department of Medical Biochemistry

Institute of Health Sciences

Gazi University

06500 Besevler, Ankara, Turkey

Phone: +90 55399837774

E-mail: suzanmuratoglu89@hotmail.com 